\title{
Systemic Disease Protection Elicited by Plant Growth Promoting Rhizobacteria Strains: Relationship Between Metabolic Responses, Systemic Disease Protection, and Biotic Elicitors
}

\author{
B. Ramos Solano, J. Barriuso Maicas, M. T. Pereyra de la Iglesia, J. Domenech, and F. J. Gutiérrez Mañero
}

Universidad San Pablo CEU, Facultad de Farmacia, P.O. Box 67, Boadilla del Monte, 28668, Madrid, Spain.

Accepted for publication 12 October 2007.

ABSTRACT

\begin{abstract}
Ramos Solano, B., Barriuso Maicas, J., Pereyra de la Iglesia, M. T., Domenech, J., and Gutiérrez Mañero, F. J. 2008. Systemic disease protection elicited by plant growth promoting rhizobacteria strains: Relationship between metabolic responses, systemic disease protection, and biotic elicitors. Phytopathology 98:451-457.

A study of plant defensive systemic responses induced by three plant growth promoting rhizobacteria (PGPR) on Arabidopsis thaliana Col 0 against Pseudomonas syringae pv. tomato DC3000 at the biochemical and transcriptional levels is reported in this paper. All three strains decreased disease severity when applied to A. thaliana prior to pathogen inoculation. At the biochemical level, each of the three strains induced ethylene (ET) when incubated with 1-amino-cyclopropane-1-carboxylic acid, and salicylic acid (SA) production in the plant. Plants treated with each of the three strains were also reduced in salicylic acid production after pathogen challenge compared to untreated controls. This effect was more marked in plants treated with Chryseobacterium balustinum AUR9, the strain most effective in decreasing disease severity. The expression
\end{abstract}

level of PR1, a transcriptional marker of the SA-dependent pathway in C. balustinum AUR9-treated plants, is fourfold that of controls while the expression of PDF1.2, a transcriptional marker for the SA-independent pathway, is not induced. C. balustinum cell wall lipopolysaccharides, being putative bacterial elicitor molecules, are able to reproduce this systemic induction effect at low doses. From these observations, we hypothesize that certain PGPR strains are capable of stimulating different systemic responses in host plants. With C. balustinum AUR9, the SAdependent pathway is stimulated first, as indicated by increases in SA levels and PR1 expression, followed by induction of the SA-independent pathway, as indicated by the increases in ET concentrations. The effects of both pathways combined with respect to disease suppression appear to be additive.

Additional keywords: induced systemic resistance, peroxidase, phenylalanine ammonia-lyase, real-time polymerase chain reaction, systemic acquired resistance.
Knowledge of rhizosphere ecology and its implications on plant physiology have dramatically changed traditional crop management practices, especially when regarding plant nutrition and defensive mechanisms $(1,19,30)$. Today, it is a widely accepted fact that certain strains of rhizosphere bacteria, referred to as plant growth promoting rhizobacteria (PGPR), stimulate plant growth and fitness (10). Many PGPR stimulate plant growth either by improving plant nutrition $(7,26)$, by releasing plant growth regulators (9), or by suppressing pathogenic organisms $(39,41)$.

Van Peer et al. (36) and Wei et al. (38) demonstrated that nonpathogenic Pseudomonas spp. strains are capable of triggering a plant-mediated resistance response in above-ground plant parts when inoculated on roots. This type of induced resistance is often referred to as rhizobacteria-mediated induced systemic resistance (ISR). In the plant, ISR starts in the roots and extends to the shoots, and is triggered by a nonpathogenic microorganism. In contrast, the defensive systemic acquired resistance (SAR) is triggered after infection by a necrotizing pathogen (27). Regardless of the eliciting microorganism, induced resistance is effective against a broad range of plant pathogens.

ISR has been reported as one of the mechanisms by which PGPR reduce plant disease, functioning through the manipulation of the physical and biochemical properties of host plants (22). PGPR-elicited ISR has been demonstrated in many plant species, including Arabidopsis spp., bean, carnation, cucumber, radish,

Corresponding author: B. Ramos Solano; E-mail address: bramsol@ceu.es

doi:10.1094/PHYTO-98-4-0451

(C) 2008 The American Phytopathological Society tobacco, and tomato (35). Because of its rapid growth rate, as well as its extensive and well characterized genetic background (18), Arabidopsis thaliana has turned out to be the model plant for investigating the relationship between PGPR-induced signal pathways in plants and ISR $(11,28,29,35)$. In A. thaliana, SAR and ISR are regulated by distinct signaling pathways. As in many other plant species, pathogen-induced SAR is associated with local and systemic increases in endogenously synthesized SA, and coupled to a coordinated expression of genes encoding pathogenesis-related (PR) proteins (12,34). In contrast, other bacteria, such as Pseudomonas fluorescens WCS417r, trigger defense responses through a pathway independent of SA and PR gene activation $(20,37)$, instead requires jasmonic acid (JA) and ethylene (ET) signaling in A. thaliana. The expression of PR1 is typically used as a marker of the SA-dependent induction pathway (16), while the plant defensive PDF1.2 is one the most useful markers for the SA-independent induction pathway (22). The metabolic responses characteristic of systemic defense mechanisms such as induction of enzymatic activities related to the hypersensitive response (peroxidases [PO] or polyphenol oxidases [PPO]), or related to phytoalexins biosynthesis (phenylalanine ammonia-lyase [PAL]) have been widely described (35). However, there are other metabolic responses triggered by nonpathogenic bacteria, that will be only appreciated upon pathogen challenge and consist in a more rapid and stronger defense expression. This phenomenon is called "priming" (4).

Both SAR and ISR defense responses are induced by certain molecules called elicitors. These are produced either by pathogenic or nonpathogenic microorganisms, many of which are cell surface-derived components. The most frequently described biotic 
elicitors, which include proteins, polysaccharides, lipopolysaccharides, or volatile compounds, are cell wall polysaccharides. Identification of elicitors is fundamental to economic exploitation of defense responses, both in agricultural and pharmaceutical purposes $(13,23,42)$.

PGPR strains belonging to the genera Pseudomonas, Bacillus, and Azospirillum have been reported to elicit growth promotion and ISR $(9,10,11,36)$, however, there is little information on the metabolic pathways involved in the systemic responses elicited by these strains. To gain a better understanding of these pathways, we chose to investigate PGPR strain effects using the Arabidopsis/Pseudomonas syringae host/pathogen model system. The specific objectives of this study were (i) to determine if PGPR strains Azospirillum brasilense Sp7 (33), Chryseobacterium balustinum AUR9, and P. fluorescens AUR6 (14) are able to induce systemic resistance in $A$. thaliana against the leaf spot pathogen $P$. syringae pv. tomato DC3000; (ii) to better understand plant metabolic responses triggered by these PGPR strains; and (iii) to determine if bacterial cell wall lipopolysaccharides (LPS) of C. balustinum are putative elicitor molecules of the systemic response.

\section{MATERIALS AND METHODS}

Bacterial strains. $P$. fluorescens AUR6 and C. balustinum AUR9 were both isolated from the rhizosphere of Lupinus albus (14) and are able to produce auxin-like compounds (1.48 and 3.7 ppm IAA-like, respectively) and siderophores, and have shown a growth promoting effect on Lupinus sp., pine and holm oak tree (15). A. brasilense $\mathrm{Sp} 7$ has been described by Tarrand et al. (33), and is capable of releasing auxins ( $8 \mathrm{ppm}$ IAA-like). All strains were maintained at $-80^{\circ} \mathrm{C}$ in tryptic soy broth TSB (yeast extract [3 g/liter], triptone [5 g/liter], and $\mathrm{ClCa}$ [0.65 g/liter] at $\mathrm{pH} 7$ ) amended with $20 \%$ glycerol. The leaf spot pathogen $P$. syringae pv. tomato DC3000 was used for challenge inoculation. This strain causes bacterial speck on the model plant $A$. thaliana and is used to study the model system for plant-pathogen interactions (35).

Cultivation of plants. A. thaliana ecotype Col 0 seeds were sown in quartz sand and watered with Hoagland's solution (Sigma, MO). Seedlings were cultivated in a growth chamber (Sanyo MLR-350H, Japan) with a 9-h light $\left(350 \mu \mathrm{E} \mathrm{s}^{-1} \mathrm{~m}^{-2}\right.$ at $24^{\circ} \mathrm{C}$ ) and 15 -h dark period $\left(20^{\circ} \mathrm{C}\right)$ at $70 \%$ relative humidity. Two-week-old seedlings, one per pot, were transplanted to $120-\mathrm{ml}$ pots, using as substrate a $12: 5$ ( $\mathrm{vol} / \mathrm{vol})$ potting soil/sand mixture $(d=665 \mathrm{~g} /$ liter $)$, autoclaved twice for $20 \mathrm{~min}$ at $121^{\circ} \mathrm{C}$ with a 24-h interval between each one. Plants were watered regularly and supplied once a week with half-strength Hoagland's solution.

Growth promotion assay. Inoculum was prepared by streaking strains from $-80^{\circ} \mathrm{C}$ onto tryptic soy agar (TSA) plates, incubating plates at $28^{\circ} \mathrm{C}$ for 24 to $30 \mathrm{~h}$, and scraping bacterial cells off plates into sterile $10 \mathrm{mM} \mathrm{SO} \mathrm{mg}_{4}$ buffer. Four treatments were defined as each of the three PGPR and the untreated control. Seven replicates consisting of three plants each were used for each treatment. Each pot was bacterized with $12 \mathrm{ml}$ of a PGPR solution with a concentration of $6.65 \times 10^{8} \mathrm{cfu} / \mathrm{ml}$, determined by the plate-dilution method, to achieve $10^{8} \mathrm{cfu} / \mathrm{g}$ substrate. Therefore, PGPR were applied when 2-week-old seedlings were transplanted. A second dose of PGPR inoculum was applied by soil drench, with $12 \mathrm{ml}$ of a PGPR solution $\left(6.65 \times 10^{8} \mathrm{cfu} / \mathrm{ml}\right)$, 3 weeks after transplant, to achieve the same inoculum density in soil. Plants were harvested 4 weeks after transplant and shoot fresh weight was determined. The experiment was repeated twice with similar results.

Induction of systemic resistance by PGPR. A separate experiment was performed to evaluate the ability of each PGPR to induce systemic resistance $\mathrm{SR}$ as measured by decrease in severity of disease caused by $P$. syringae pv. tomato DC3000. The same experimental design described for the growth promotion assay was followed, and 1 week after the second dose of PGPR, plants were challenged with the leaf spot pathogen $P$. syringae pv. tomato DC3000. Pathogen inoculum was prepared by growing cells in TSB medium overnight at $28^{\circ} \mathrm{C}$ under shaking. After centrifugation, bacterial cells were resuspended in $10 \mathrm{mM} \mathrm{MgSO}_{4}$ buffer and the concentration was adjusted to $10^{7} \mathrm{cfu} / \mathrm{ml}$. Plants were incubated for $24 \mathrm{~h}$ in $100 \%$ humidity to ensure stomatal opening, after which the aerial system of each plant was dipped into a $10^{7} \mathrm{cfu} / \mathrm{ml}$ solution of $P$. syringae DC3000 in $10 \mathrm{mM}$ $\mathrm{MgSO}_{4}$ buffer. Inoculated plants were kept under high humidity conditions for the following $24 \mathrm{~h}$. Nonpathogen-challenged controls of all treatments were mock-inoculated with $10 \mathrm{mM}$ $\mathrm{MgSO}_{4}$ buffer and kept in parallel to ensure disease progress. Disease severity was determined as the percentage of leaves with chlorotic spots over the total, per plant, 1 week after pathogen challenge. The experiment was repeated twice with similar results.

Extraction and quantification of SA. SA was determined in PGPR-treated plants and controls that were not pathogen-challenged 1 week after the second PGPR treatment (growth promotion assay). SA was also determined in the pathogen-challenged plants 1 week after pathogen challenge. A total of seven replicates consisting of three plants each were used. Roots from the three plants in each replicate were pooled to obtain $1 \mathrm{~g}$ fresh weight. After freezing in liquid nitrogen, roots were powdered with a mortar and pestle and SA was extracted as described by Bowlin et al. (3). For the analysis of free and conjugated SA, $1.25 \mu \mathrm{g}$ of the internal standard ortho-anisic acid was added per gram of fresh weight. SA content was analyzed by high-performance liquid chromatography (HPLC) according to Rasmussen et al. (25). The experiment was repeated twice with similar results.

Enzyme activity detection bioassay. Enzyme determinations were performed in PGPR-treated plants and control plants that were not pathogen-challenged 1 week after the second PGPR treatment (growth promotion assay), and in the pathogen-challenged plants, 1 week after pathogen challenge. Three replicates consisting of seven plants each were used for each activity. The experiment was repeated twice with similar results.

To determine ET production during the response, plant shoots were excised, dipped in $1 \mathrm{mM} 1$-amino-cyclopropane-1-carboxylic acid (ACC) solution, and incubated in sealed flasks for $48 \mathrm{~h}$. Five hundred microliters of air inside the flask was removed with a Hamilton syringe and injected in a high resolution gas chromatography (HRGC) a GC HP 6890, as described in Grant and Binkley (8). All enzyme activities were determined in plant root extracts, prepared as follows. Roots from plants within a replicate were pooled to obtain $1 \mathrm{~g}$ fresh weight, rinsed with tap water to remove substrate debris, dried in liquid nitrogen, and powdered using a mortar and pestle. PO and PAL activity were determined according to Chen et al. (5), modified in the following manner: $1 \mathrm{~g}$ of powdered root sample was resuspended in $1 \mathrm{ml}$ of $10 \mathrm{mM}$ sodium phosphate buffer $(\mathrm{pH} 7)$, shaken, and centrifuged twice at 5,000 $\times g$. The supernatant was recovered and used to determine enzyme activity. Protein concentration was determined in the plant extract by the Bradford method according to the manufacturer's instructions (Sigma, MO). All enzymatic activity was expressed as units/mg enzyme.

PO activity was determined using $100 \mu \mathrm{l}$ of the prepared sample extract, obtained as described above, added to $792 \mu \mathrm{l}$ of sodium phosphate buffer $5 \mathrm{mM}(\mathrm{pH} 6)$ and mixed with $7.5 \mu \mathrm{l}$ of guaiacol ( $60 \mathrm{mM}$ final concentration). The reaction was started by the addition of $100 \mu \mathrm{l}$ of hydrogen peroxide $(0.6 \mathrm{M})$ to the mixture, and increase in absorbance was measured for the first minute at $\lambda 470 \mathrm{~nm}$. A standard curve was calculated with horseradish PO (Sigma, MO), and PO activity was expressed as mU of PO per microgram of protein. One unit is defined as the amount of enzyme that will form $1 \mathrm{mg}$ of purpurogallin from pyrogallol in $20 \mathrm{~s}$ at $\mathrm{pH} 6$ at $20^{\circ} \mathrm{C} \mathrm{(5).}$ 
To determine PAL activity, $100 \mu \mathrm{l}$ of sample extract was mixed with $900 \mu \mathrm{l}$ of $6 \mu \mathrm{M}$ L-phenylalanine and $0.5 \mathrm{M}$ Tris-HCl buffer $(\mathrm{pH} 7)$. The mixture was placed in a water bath at $37^{\circ} \mathrm{C}$ for $70 \mathrm{~min}$. Absorbance at $\lambda 290 \mathrm{~nm}$ was determined before and after the incubation to calculate the increase in absorbance. A standard curve was calculated with PAL from Rhodotorula glutinis (Sigma, $\mathrm{MO}$ ), and PAL activity was expressed as $\mathrm{mU}$ of peroxidase per microgram of protein. One unit of the commercial standard is defined as the amount of enzyme that transforms $1 \mu \mathrm{mol} \mathrm{L}$-phenylalanine to trans-cinnamate and $\mathrm{NH}_{3}$ per min at $\mathrm{pH} 8.5$ at $30^{\circ} \mathrm{C} \mathrm{(5).}$

Transcriptional markers. RNA extractions from $A$. thaliana leaves were performed $24 \mathrm{~h}$ after the last PGPR bacterization (experimental design of "growth promotion assay" section) using the RNeasy Plant Mini Kit (Qiagen, CA). Real-time polymerase chain reaction (RT-PCR) were performed using $500 \mathrm{ng}$ of RNA as template in $20 \mu \mathrm{l}$ consisting of $1 \times$ RT-PCR buffer, $2.5 \mathrm{mM} \mathrm{MgCl} 2$, $1 \mathrm{mM}$ dNTP Blend, $10 \mathrm{U}$ of RNase Inhibitor, $1.25 \mu \mathrm{M}$ Random Hexamer, and $15 \mathrm{U}$ of MultiScribe Reverse Transcriptase (Applied Biosystems, CA). Reactions were incubated for $10 \mathrm{~min}$ at $25^{\circ} \mathrm{C}$ and $12 \mathrm{~min}$ at $42^{\circ} \mathrm{C}$ in a GeneAmp 2700 thermocycler (Applied Biosystems, CA). Five microliters of reactions was used as template for real time PCR with specific primers for the ACTIN1 as housekeeping gene (ACT[PCRQ]F 5'-CGTTGCACCACCTGAAAGG-3' and ACT[PCRQ]R 5'-GGGAAGCAAGAATGGAACCA-3'), and for the transcriptional markers PR1 (PR1qF 5'-GTCTCCGCCGTGAACATGT-3' and PR1qR 5'-CGTGTTCGCAGCGTAGTTGT-3'), and PDF1.2 (PDF1.2qnew2F 5'-TTGTTCTCTTTGCTGCTTTCGA-3' and PDF1.2qnew2R 5'TTGGCTTCTCGCACAACTTCT- $3^{\prime}$ ). The reaction was performed using 300nM of each primer and $1 \times$ SYBR Green PCR Master Mix (Applied Biosystems, CA) in a $20 \mu \mathrm{l}$. PCR conditions were 40 cycles, with an annealing temperature of $60^{\circ} \mathrm{C}$ in an ABI Prism 7700 system for quantitative PCR (Applied Biosystems). A standard curve was calculated for each primer with four serial dilutions, and data were normalized using actin gene expression. The experiment was performed twice, with three replicates, using leaves from seven plants for each replicate. Similar results were obtained in both experiments.

Extraction of LPSs from $C$. balustinum AUR for ISR assay. LPSs from $C$. balustinum were extracted from $72 \mathrm{~h}$ bacterial cultures grown in triptone yeast medium (TY) (yeast extract [3 g/liter], triptone [5 g/liter], ClCa [0.65 g/liter], and agar [15 g/liter] at $\mathrm{pH} 7)$ at $28^{\circ} \mathrm{C}$ with continuous shaking. Cultures were centrifuged and pellets were extracted with butanol-water (1:4), followed by dialysis against $4: 1$ of deionized water for 4 days with several water changes. The final dialyzed suspension was lyophilized to dryness. To partially purify the cell-attached polysaccharides, the lyophilized sample was dissolved in $40 \mathrm{ml}$ of $5 \mathrm{mM}$ of $\mathrm{MgCl}_{2}$. DNase I (Roche) was added to a final concentration of $1 \mathrm{mg} \mathrm{ml}^{-1}$ and the mixture was incubated at $30^{\circ} \mathrm{C}$ for

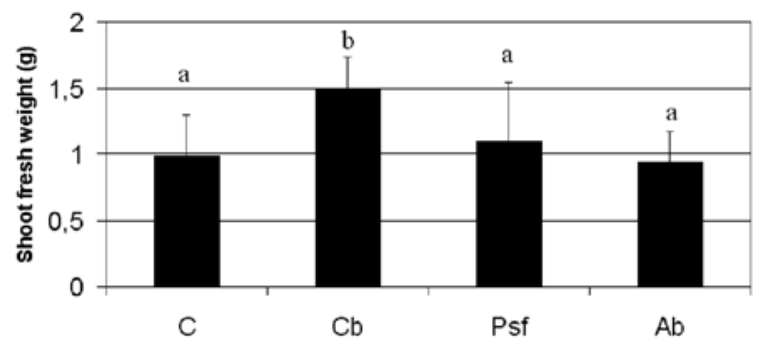

Fig. 1. Shoot fresh weight (g) of 6-week-old Arabidopsis thaliana plants treated 2 and 5 weeks after germination with plant growth promoting rhizobacteria strains Chryseobacterium balustinum AUR9 (Cb), Pseudomonas fluorescens AUR6 (Pfs), or Azospirillum brasilense Sp7 (Ab), and untreated controls (C). Values are the mean of seven replicates with three plants each $(n=21)$. Bars indicate standard errors and different letters indicate the existence of significant differences according to Tukey test $(P<0.05)$.
$4 \mathrm{~h}$. Pronase (Roche) was then added to a concentration of $1.5 \mathrm{mg}$ $\mathrm{ml}^{-1}$, and the incubation was continued at $50^{\circ} \mathrm{C}$ for $4 \mathrm{~h}$. The mixture was then centrifuged at $15,000 \times g$ for $15 \mathrm{~min}$, and the supernatant was dialyzed and lyophilized.

A. thaliana Col 0 seeds were pregerminated on Murashige and Skoog (MS) agar (Sigma, MO) and transplanted after 2 weeks to six well-plates (Corning Inc., NY) with MS agar with one plant per well. One week after transplanting, LPS preparations were dissolved on MS agar at two different concentrations (5 and $50 \mathrm{ppm}$ ) for the first experiment and at three different concentrations $(5,25$, and $50 \mathrm{ppm})$ for the second experiment. One week after LPS application, plants were challenged with the $P$. syringae DC3000 by spotting a $10-\mu \mathrm{l}$ suspension containing $10^{7} \mathrm{cfu} / \mathrm{ml}$ in $10 \mathrm{mM} \mathrm{MgSO}_{4}$ on the upper side of each leaf of each plant. The drop was allowed to dry without movement. After 1 week, plants were scored for symptoms. Disease severity was determined by calculating the percentage of leaves on each plant showing disease symptoms relative to total leaves per plant (28). Twenty one plants were used for each treatment, and the experiment was repeated twice with similar results.

Statistical analysis. Unidirectional analyses of variance were carried out to evaluate bacterial effects on growth and disease severity. When differences were significant, a Tukey test $(P<$ $0.05)$ was performed with the computer program Statgraphics plus 5.1 (Statistical Graphics Corp.).

\section{RESULTS}

Growth promotion assay. The ability of the three PGPR bacterial strains ( $C$. balustinum AUR9, $P$. fluorescens AUR6, and A. brasilense $\mathrm{Sp} 7$ ) to enhance $A$. thaliana growth as measured by shoot fresh weight was evaluated (Fig. 1). C. balustinum AUR9 significantly increased fresh weight up to $40 \%$ over the untreated control plants. In contrast, plants treated with either of the other two strains did not exhibit significant changes in growth compared with the untreated control plants.

Induction of systemic resistance by PGPR strains. The ability of these strains to decrease disease severity in A. thaliana $\mathrm{Col} 0$ against $P$. syringae pv. tomato DC3000 was recorded (Fig. 2). Each of the three strains reduced disease severity compared to untreated control plants. C. balustinum AUR9 performed best at reducing disease severity by more than $72 \%$ compared with untreated, pathogen-inoculated control plants. To a lesser degree, $P$. fluorescens AUR6 and A. basilense Sp7 decreased disease severity by 23.6 and $29.7 \%$, respectively.

Free and glycosylated SA were determined in PGPR-treated and untreated control plants with and without pathogen challenge (Fig. 3). Figure 3A shows results of PGPR-treated plants that were not pathogen-challenged and the untreated control plants. Total SA levels were significantly higher in all plants treated with

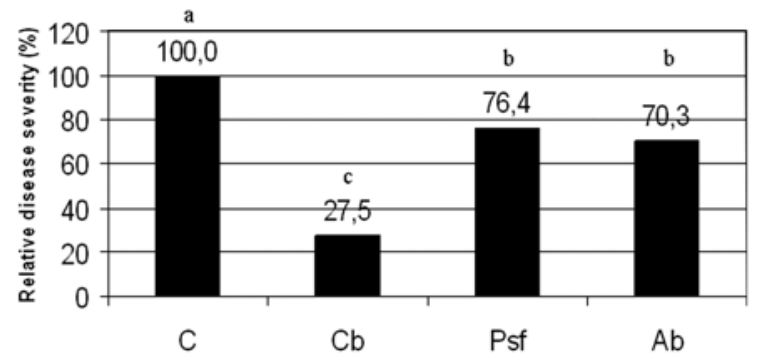

Fig. 2. Relative disease severity in 7-week-old Arabidopsis thaliana plants treated with plant growth promoting rhizobacteria strains Chryseobacterium balustinum AUR9 (Cb); Pseudomonas fluorescens AUR6 (Pfs), or Azospirillum brasilense $\mathrm{Sp} 7(\mathrm{Ab})$, and untreated controls $(\mathrm{C})$ and challenged with the leaf spot pathogen Pseudomonas syringae pv. tomato DC3000 $(n=21)$. Different letters indicate significant differences according to Tukey test $(P<0.05)$. 
PGPR strains compared with untreated control plants, with the effect being especially marked in A. brasilense-treated plants. Free SA levels were significantly greater in plants treated with $C$. balustinum AUR9 and P. fluorescens AUR6, while glycosylated SA levels were significantly greater in A. brasilense-treated plants compared with untreated control plants. In contrast, total SA levels were lower in pathogen-challenged plants treated with C. balustinum AUR9 or P. fluorescens AUR6 compared with untreated control plants (Fig. 3B). Surprisingly, however, no significant differences were observed in plants treated with $A$. brasilense Sp7 compared with the control plants. Similar trends were observed with both glycosylated SA and free SA in pathogenchallenged plants.

Detection of enzyme activities associated with ISR and ET production in plants treated with PGPR strains. Figure 4

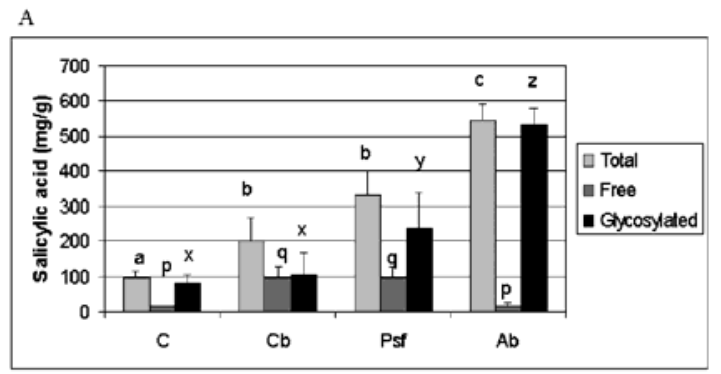

B

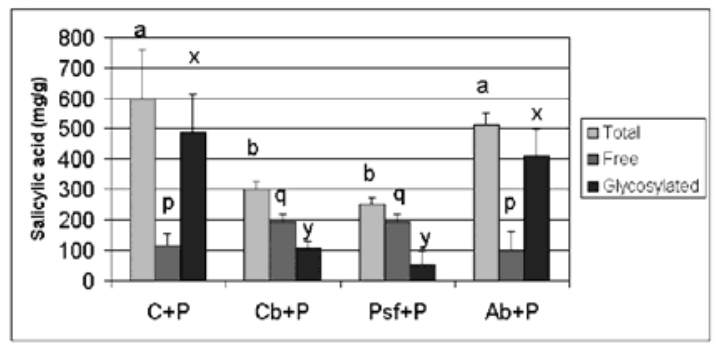

Fig. 3. Total, free, and glycosylated salicylic acid (SA) levels in Arabidopsis thaliana plants treated with $\mathbf{A}$, plant growth promoting rhizobacteria (PGPR) alone and $\mathbf{B}$, in combination with the leaf spot pathogen Pseudomonas syringae pv. tomato DC3000. For PGPR treatment alone, plants were treated 2 and 5 weeks after germination with Chryseobacterium balustinum AUR9 (Cb), Pseduomonas fluorescens AUR6 (Psf), Azospirillum brasilense Sp7 (Ab), or buffer as the untreated control (C) and assayed for SA 1 week after the final treatment. For pathogen-inoculated plants, plants were treated with PGPR the same as in $\mathbf{A}$, followed by inoculation with the pathogen (+P) 1 week later. Plants were assayed for SA content 1 week after pathogen inoculation. Data are the mean of seven replicates with three plants each $(n=21)$. Different letters indicate significant differences between values for total $(\mathrm{a}, \mathrm{b}, \mathrm{c}$, and $\mathrm{d})$, free (p, q, r, and s) and glycosylated SA (x, y, and z), according to Tukey test $(P<0.05)$.

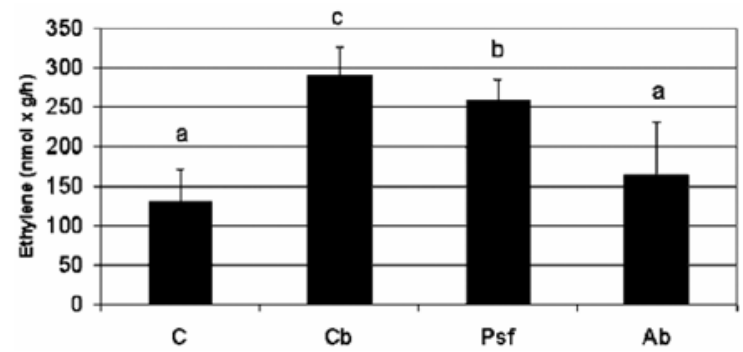

Fig. 4. Ethylene production after priming with $1 \mathrm{mM}$ ACC in 6-week-old Arabidopsis thaliana plants treated 2 and 5 weeks after germination, with plant growth promoting rhizobacterium strains Chryseobacterium balustinum AUR9 (Cb), Pseudomonas fluorescens AUR6 (Pfs), or Azospirillum brasilense $\mathrm{Sp} 7(\mathrm{Ab})$, and untreated controls $(\mathrm{c})(n=21)$. Bars indicate standard errors and different letters indicate significant differences according to Tukey test $(P<0.05)$. shows data from ET production after incubation with ACC. All PGPR-treated plants increased ET production when primed with ACC as compared with the non-PGPR control and this increase was statistically significant in $C$. balustinum AUR9 and $P$. fluorescens AUR6-treated plants.

Results from PO activity are shown in Figure 5. In nonpathogen-challenged plants, only those treated with $A$. brasilense had significantly higher PO levels than untreated controls (Fig. 5A). In contrast, for pathogen-challenged plants, only those treated with $C$. balustinum AUR9 before the pathogen challenge showed significantly (50\%) lower PO values (Fig. 5B).

Figure 6 shows results from PAL activity in PGPR treated plants and controls. PAL activity is significantly increased, especially under the influence of $C$. balustinum AUR9 (eightfold) and P. fluorescens AUR6 (sixfold) (Fig. 6A). However, in pathogen-challenged plants (Fig. 6B), only P. fluorescens AUR6 treated plants showed PAL levels significantly higher than the controls.

Expression levels of PR1 and PDF1.2 were evaluated on C. balustinum AUR9-treated plants, $24 \mathrm{~h}$ after the second bacterization. Figure 7 shows that PR1 levels were fourfold in C. balustinum AUR9-treated plants than those found in the untreated controls, while expression of PDF1.2 was not affected by the PGPR.

ISR assay with LPSs from $C$. balustinum AUR9. Since $C$. balustinum AUR9 was the most effective strain in eliciting ISR as evaluated by reducing disease severity and promoting plant growth, we tested whether bacterial cell wall LPSs were extracted from the strain and assayed on $A$. thaliana $\mathrm{Col} 0$ against $P$. syringae pv. tomato DC3000. In 2 different experiments, LPS inoculated at the lowest concentrations of $5 \mu \mathrm{g} / \mathrm{liter}$ was able to reduce disease severity by more than $50 \%$ compared with untreated disease control plants (Fig. 8). In contrast, inoculation of LPS at higher concentrations of 25 or $50 \mu \mathrm{g} /$ liter was not effective.

\section{DISCUSSION}

This paper reports on the plant defense systemic responses induced by three PGPR on $A$. thaliana Col 0 against the leaf spot

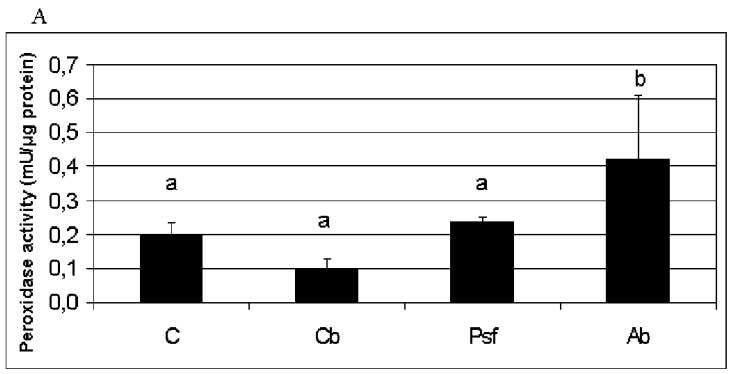

B

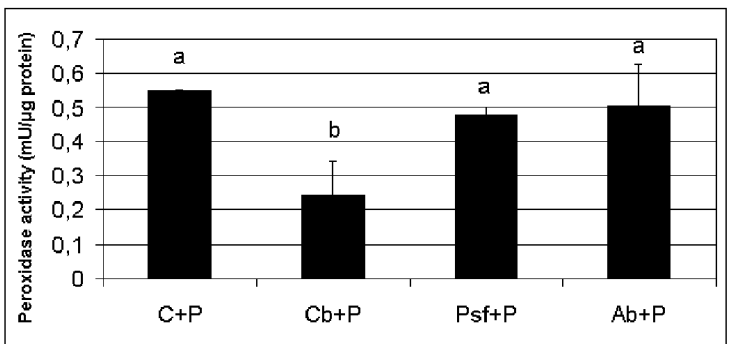

Fig. 5. Peroxidase activity determined in Arabidopsis thaliana plants A, treated 2 and 5 weeks after germination with plant growth promoting rhizobacterium strains Chryseobacterium balustinum AUR9 (Cb), Pseudomonas fluorescens AUR6 (Pfs), or Azospirillum brasilense $\mathrm{Sp} 7(\mathrm{Ab})$ and unteatred controls (c); and B, 1 week after pathogen challenge with the leaf spot pathogen Pseudomonas syringae pv. tomato DC3000 (P). Data are the mean of seven replicates with 3 plants each $(n=21)$. Bars indicate standard errors and different letters indicate the existence of significant differences according to Tukey test $(P<0.05)$. 
pathogen $P$. syringae DC3000 at the biochemical and transcriptional levels, as well as the putative role of bacterial LPSs as elicitor molecules. It is widely accepted that in certain rhizobacterial-plant systems, rhizobacteria are able to decrease disease severity upon pathogen challenge (35). This response is caused by induction of gene expression and activation of enzymes involved in blocking the pathogen infection process. The three PGPR strains tested in this study have previously exhibited a growth promotion effect on different plant species such as lupin (14), pine, and holm oak tree (15). Results here showed a positive effect of C. balustinum AUR9 on A. thaliana growth. The significant increases detected in shoot weight (Fig. 1) suggest that growth promotion is mediated through auxin production, given that all three strains are able to release auxin-like compounds to culture media $(14,31,33)$.

Regarding plant protection against DC3000, all three strains decreased disease severity (Fig. 2). Again, C. balustinum AUR9 was the most effective in decreasing disease severity compared with the other PGPR strains. The strong eliciting ability of the plant's defense responses achieved by C. balustinum AUR9 is striking and, to our knowledge, is the first report for any Chryseobacterium strain.

We linked abilities of all the PGPR strains to decrease disease severity with activation of enzyme activities of the phenylpropanoid pathway (PAL) and hypersensitive response (PO), and production of signal transduction molecules (SA and ET) involved in systemic induction of disease protection.

SA and ET are phytohormones involved in systemic responses related to defense processes (21). SA plays a key role in SAR response provoked by pathogen attack in many plant species (35). However, increases in SA levels are not typically detected when plants are previously treated with a PGPR strain capable of decreasing disease severity (6). Our results showed (Fig. 5) that the three PGPR strains increased SA levels on Arabidopsis. SA production can be attributed to the effect of PGPR identified as
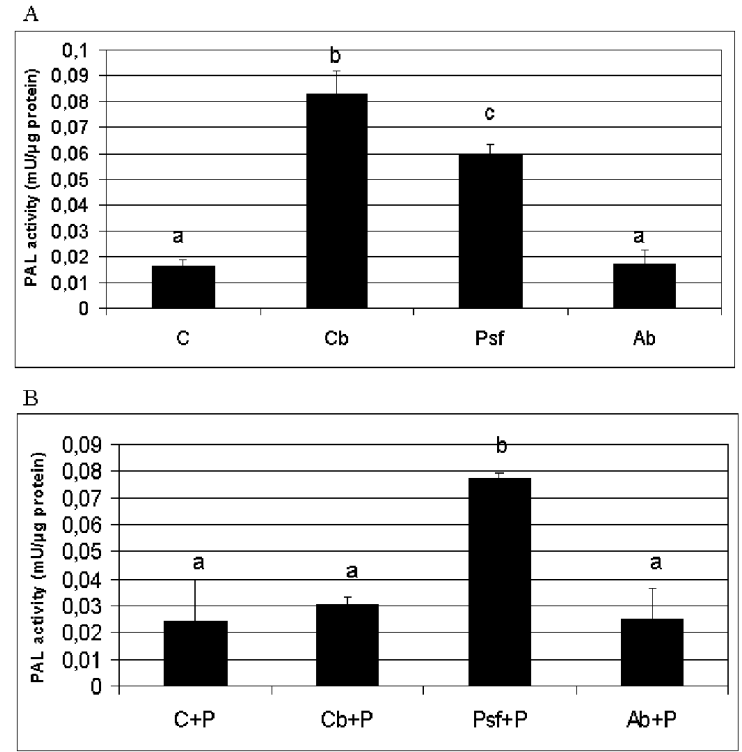

Fig. 6. Phenylalanine ammonia-lyase (PAL) activity determined in Arabidopsis thaliana plants. A, Plants treated with plant growth promoting rhizobacteria (PGPR) strains Chryseobacterium balustinum AUR9 (Cb), Pseudomonas fluorescens AUR6 (Pfs), or Azospirillum brasilense Sp7 (Ab) and untreated controls (c). Plants were treated 2 and 5 weeks after germination and sampled for activity 1 week after the final treatment. B, Plants treated with PGPR bacteria (as in A) and challenged with the leaf spot pathogen Pseudomonas syringae pv. tomato DC3000 (P) 1 week after the final treatment. Plants were sampled for enzyme activity 1 week after pathogen challenge. In all cases, data are the mean of seven replicates with three plants each $(n=21)$. Bars indicate standard errors and different letters indicate significant differences according to Tukey test $(P<0.05)$. avirulent pathogens (2). These authors reported that inoculation of the avirulent pathogen prior to pathogen challenge blocks the increase in SA levels detected in pathogen-challenged controls. Our results are consistent with these data since A. brasilensis Ab is the strain that shows the lowest level of defense upon pathogen challenge (Fig. 2), causes the highest increases in SA (Fig. 3A) and is unable to block the SA peak after pathogen challenge (Fig. 3B), opposite to $C$. balustinum AUR9. In summary, the protection conferred by the assayed PGPR is inversely related to SA production and coincides with reduction of SA accumulation in PGPR-treated plants.

Results from biochemical marker (SA and ET) experiments showed that the most effective strain in decreasing disease severity, C. balustinum AUR9, may stimulate both SA-dependent and SA-independent pathways, since previous studies indicate that the ISR response involves JA and ET and not SA $(36,38)$. We measured ET production after incubation with its precursor, ACC, since as demonstrated by Pieterse (22), the role of ET on ISRmediated response is not detected by increases of this molecule, but they are detected in its sensitivity, the so-called "priming response". Consistent with this observation, our results showed that those PGPR strains that achieved higher reduction of disease severity caused the release of more ET in plants after incubation with ACC (Fig. 4). That is, C. balustinum AUR9-treated plants presented the highest production of ET, followed by plants treated with P. fluorescens AUR6, A. brasilensis Ab and the untreated controls. When these data are related to SA production, it may be concluded that those strains most effective in decreasing disease severity induce more ET, but less SA, production in plants. They also block the SA peak upon pathogen challenge, as seen in $C$. balustinum AUR9.

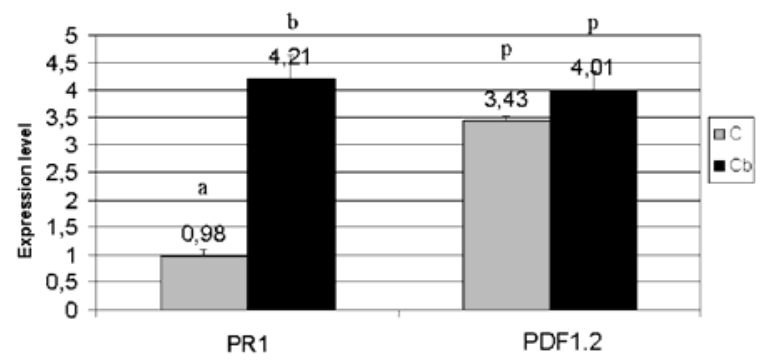

Fig. 7. Relative gene expression levels of the transcriptional markers PR1 (salicylic acid [SA]-dependent pathway) and PDF1.2 (SA-independent pathway), expressed as $\Delta \mathrm{Ct}$ values normalized to ACTIN1 gene expression, in 6-week-old Arabidopsis thaliana plants untreated controls (C) and Chryseobacterium balustinum AUR9 $(\mathrm{Cb})$ treated plants. Samples were taken $24 \mathrm{~h}$ after the second plant growth promoting rhizobacteria (PGPR) dose. Data are the mean of seven replicates with three plants each $(n=21)$. Bars indicate standard errors and different letters indicate the existence of significant differences according to Tukey test $(P<0.05)$.

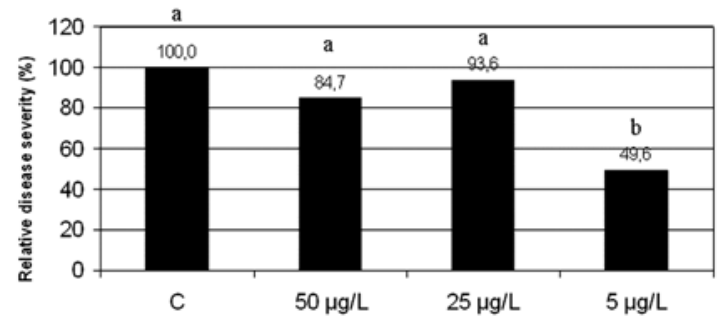

Fig. 8. Relative disease severity in Arabidopsis thaliana plants inoculated with lipopolysaccharides (LPSs) from Chryseobacterium balustinum AUR9 (Cb) and noninoculated controls (C) 1 week after pathogen challenge with the leaf spot pathogen Pseudomonas syringae pv. tomato DC3000 (P). First assay (a) with two different concentrations, and second assay (b) with three different concentrations $(n=21)$. Letters indicate the existence of significant differences according to Tukey test $(P<0.05)$. 
Our data suggest that the primary mechanism by which $C$. balustinum AUR9 suppresses disease is through elicitation of the SA-independent pathway related to systemic resistance. However, other responses different to those described by Pieterse (21) or van Loon (35), cannot be ruled out. PGPR may elicit different pathways simultaneously conferring additive responses that are more effective than single-elicited pathways (17).

Expression levels of PR1 as the molecular marker for the SAdependent pathway, and PDF1.2, as the molecular marker for the SA-independent pathway, differed in C. balustinum AUR9-treated plants (Fig. 7). These results, together with those from SA levels (Fig. 3A), confirm that this strain in some way involves SA in the transduction of the defense signal prior to pathogen challenge. We expected increases in ET to parallel increases in the expression of PDF1.2, which was not detected. Based on these observations, it could be proposed that $C$. balustinum AUR9 is able to elicit both SA-dependent and SA-independent pathways relative to pathogen challenge. The proposed sequence of events could be as follows: first, based on the increase on SA levels and PR1 expression, the SA pathway is stimulated, behaving similar to an avirulent pathogen; second, the SA-independent pathway is stimulated based on the increases in ET, coupled to blockage of SA-dependent pathway post-pathogen challenge. Additionally, the effects seem to be additive since the results show a decrease of disease severity much greater than any of the other strains.

PAL, the enzymatic activity related to phenylpropanoid metabolism, is known to be involved in the plant defense response to the pathogen (35). Our results are consistent with this fact, and increases in PAL parallel disease protection induced by PGPR. Ramamoorthy et al. (24) reported similar results in tomato. In their study, PGPR-treated plants showed higher PAL activity for a longer time irrespective of pathogen challenge. Conversely, Silva et al. (32) reported a peak of PAL activity in tomato that decreased 1 week after PGPR treatment. Our results support both situations, depending on the specific PGPR strain used as a treatment. C. balustinum AUR9-treated plants did not show increased PAL activity 1 week after pathogen challenge, while these levels were high on $P$. fluorescens AUR6-treated plants, confirming the differential response.

PO is key in the lignin biosynthesis process, and its role on formation of cell wall barriers has been reported in the SAR response. Similar to PAL, several studies have reported on PO activation after PGPR challenge. Interestingly, the two strains that conferred more disease protection showed higher increases in PAL while not increasing PO levels, whereas A. brasilense Ab did increase PO and PAL, and conferred less protection.

Our results suggest that two different responses to pathogen challenge are possible and are dependent upon the specific PGPR strain. One is very effective at decreasing disease severity and involves the ET pathway and an increase in phenylpropanoid metabolism. The second response involves SA coupled to an increase in PO, which has little effect on disease protection.

Based on the effectiveness of $C$. balustinum AUR9 to elicit host responses and suppress disease, we were interested in identifying a putative bacterial elicitor of systemic resistance. The decrease in disease severity achieved by LPSs from $C$. balustinum AUR9 (Fig. 8) demonstrate that these molecules are involved in elicitation. Only the lowest dose assayed was effective, suggesting a receptor-mediated response consistent with that proposed by Yamaguchi et al. (40).

In summary, the PGPR $C$. balustinum AUR9 was effective for induction of systemic resistance in A. thaliana against the leaf spot pathogen $P$. syringae DC3000. In this plant species, both the SA-dependent and SA-independent pathways are elicited with an additive effect by this PGPR, and its LPSs at low doses are able to reproduce this systemic induction effect. Application of LPSs appears as a promising alternative to agricultural cropping practices as they are directed at lowering chemical inputs.

\section{ACKNOWLEDGMENTS}

Founded by Ministerio de Educación y Ciencia (Spain), projects AGL 2002-04188-C06-05 and AGL 2005-07923-C05-02. We thank B. Crilly for editorial help.

\section{LITERATURE CITED}

1. Andrews, J. H., and Harris, R. F. 2000. The ecology and biogeography of microorganisms on plant surfaces. Annu. Rev. Phytopathol. 38:145-180.

2. Block, A., Schmelz, E., O’Donnell, P. J., Jones, J. B., and Klee, H. J. 2005. Systemic acquired tolerance to virulent bacterial pathogens in tomato. Plant Physiol. 138:1481-1490.

3. Bowling, S. A., Guo, A., Cao, H., Gordon, A. S., Klessig, D. F., and Dong, X. 1994. A mutation in Arabidopsis that leads to constitutive expression of systemic acquired resistance. Plant Cell 6:1845-1857.

4. Conrath, U., Pieterse, C. M. J., and Mauch-Mani, B. 2002. Priming in plant-pathogen interactions. Trends Plant Sci. 7:210-216.

5. Chen, C., Belanger, R. R., Benhamau, N., and Paulitz, T. C. 2000. Defense enzymes induced in cucumber roots by treatment with plant growth promoting rhizobacteria (PGPR) and Pythium aphanidermatum. Physiol. Mol. Plant Pathol. 56:13-23.

6. de Meyer, G., Capieau, K., Audenaert, K., Buchala, A., Metraux, J. P., and Hofte, M. 1999. Nanogram amounts of salicylic acid produced by the rhizobacterium $P$. aeruginosa 7NSK2 activate the systemic acquired resistance pathway in bean. Mol. Plant-Microbe Interact. 12:450-458.

7. Glick, B. R. 1995. The enhancement of plant growth by free-living bacteria. Can. J. Microbiol. 41:109-117

8. Grant, D., and Binkley, D. 1987. Rates of free-living nitrogen fixation in some piedemont forest types. For. Sci. 33:548-551.

9. Gutiérrez Mañero, F. J., Ramos Solano, B., Probanza, A., Mehouachi, J., Tadeo, F. R., and Talon, M. 2001. The plant growth-promoting rhizobacteria Bacillus pumilus and Bacillus licheniformis produce high amounts of physiologically active gibberellins. Physiol. Plantarum. 111:1-7.

10. Kloepper, J. W., Leong, J., Teintze, M., and Schroth, M. N. 1980. Enhanced plant growth by siderophores produced by plant growth promoting rhizobacteria. Nature 286:885-886.

11. Kloepper, J. W., Ryu, C. M., and Zhang, S. A. 2004. Induced systemic resistance and promotion of plant growth by Bacillus spp. Phytopathology 94:1259-1266.

12. Lawton, K., Weymann, K., Friedrich, L., Vernooij, B., Uknes, S., and Ryals, J. 1995. Systemic acquired resistance in Arabidopsis requires salicylic acid but not ethylene. Mol. Plant-Microbe Interact. 8:863-870.

13. Leeman, M., Vanpelt, J. A., Denouden, F. M., Heinsbroek, M., Bakker, P. A. H. M., and Schippers, B. 1995. Induction of systemic resistance against Fusarium wilt of radish by lipopolysaccharides of Pseudomonas fluorescens. Phytopathology 85:1021-1027.

14. Lucas García, J. A., Probanza, A., Ramos, B., and Gutiérrez Mañero, F. J. 2001. Genetic variability of rhizobacteria from wild populations of four Lupinus species based on PCR-RAPDs. J. Plant Nutr. Soil Sci. 164:1-7.

15. Lucas García, J. A., Domenech, J., Santamaría, C., Camacho, M., Daza, A., and Gutiérrez Mañero, F. J. 2004. Growth of forest plants (pine and holm-oak) inoculated with rhizobacteria: relationships with microbial community structure and biological activity of each rhizosphere. Environ. Exp. Bot. 52:239-251.

16. Martin, G. B., Bogdanove, A. J., and Sessa, G. 2003. Understanding the functions of plant disease resistance proteins. Annu. Rev. Plant Biol. 54:23-61.

17. Nunkel, B. N., and Brooks, D. M. 2002. Crosstalk between signaling pathways in pathogen defense. Curr. Opin. Plant Biol. 5:325-331.

18. O'Callaghan, K. J., Dixon, R. A., and Cocking, E. C. 2001. Arabidopsis thaliana: A model for studies of colonization by non-pathogenic and plant-growth-promoting rhizobacteria. Aust. J. Plant Physiol. 28:975-982.

19. O’Donnell, A. G., Seasman, M., Macrae, A., Waite, I., and Davies, J. T. 2000. Plants and fertilisers as drivers of change in microbial community structure and function in soils. Plant Soil 232:135-145.

20. Pieterse, C. M. J., van Wees, S. C. M., Hoffland, E., van Pelt, J. A., and van Loon, L. C. 1996. Systemic resistance in Arabidopsis induced by biocontrol bacteria is independent of salicylic acid accumulation and pathogenesis-related gene expression. Plant Cell 8:1225-1237.

21. Pieterse, C. M. J., van Wees, S. C. M., van Pelt, J. A., Knoester, M., Laan, R., Gerrits, N., Weisbeek, P. J., and van Loon, L. C. 1998. A novel signaling pathway controlling induced systemic resistance in Arabidopsis. Plant Cell 10:1571-1580.

22. Pieterse, C. M. J., Van Wees, S. C. M., Ton, J., Van Pelt, J. A., and Van Loon, L. C. 2002. Signalling in rhizobacteria-induced systemic resistance in Arabidopsis thaliana. Plant Biol. 4:535-544.

23. Radman, R., Saez, T., Bucke C., and Keshavaraz, T. 2003. Elicitation of plants and microbial cell systems. Biotechnol. Appl. Biochem. 37:91-102. 
24. Ramamoorthy, V., Raguchander, T., and Samiyappan, R. 2002. Induction of defense-related proteins in tomato roots treated with Pseudomonas fluorescens Pf1 and Fusarium oxysporum f. sp. lycopersici. Plant Soil. 239:55-68.

25. Rasmussen, J. B., Hammerschmidt, R., and Zook, M. N. 1991. Systemic induction of salicylic-acid accumulation in cucumber after inoculation with Pseudomonas syringae pv. syringae. Plant Physiol. 97:1342-1347.

26. Rodríguez, H., and Fraga, R. 1999. Phosphate solubilizing bacteria and their role in plant growth promotion. Biotechnol. Adv. 17:319-339.

27. Ryals, J. A., Neuenschwander, U. H., Willits, M. G., Molina, A., Steiner, H. Y., and Hunt, M. D. 1996. Systemic acquired resistance. Plant Cell 8:1809-1819.

28. Ryu, C. M., Hu, C. H., Reddy, M. S., and Kloepper, J. W. 2003. Different signaling pathways of induced resistance by rhizobacteria in Arabidopsis thaliana against two pathovars of Pseudomonas syringae. New Phytol. 160:413-420.

29. Ryu, C. M., Murphy, J. F., Mysore, K. S., and Kloepper, J. W. 2004. Plant growth-promoting rhizobacteria systemically protect Arabidopsis thaliana against Cucumber mosaic virus by a salicylic acid and NPR1-independent and jasmonic acid-dependent signaling pathway. Plant J. 39:381-392.

30. Schloter, M., Lebuhn, M., Heulin, T., and Hartmann, A. 2000. Ecology and evolution of bacterial microdiversity. FEMS Microbiol. Rev. 24:647660 .

31. Selvadurai, E. L., Brown, A. E., and Hamilton, J. T. G. 1991. Production of indole-3-acetic-acid analogs by strains of Bacillus cereus in relation to their influence on seedling development. Soil Biol. Biochem. 23:401-403.

32. Silva, H. S. A., Romeiro, R. D., Macagnan, D., Halfeld-Vieira, B. D., Pereira, M. C. B., and Mounteer, A. 2004. Rhizobacterial induction of systemic resistance in tomato plants: Non-specific protection and increase in enzyme activities. Biol. Control 29:288-295.

33. Tarrand, J. J., Krieg, N. R., and Dobereiner, J. 1978. A Taxonomic study of the Spirillum lipoferum group with description of a new genus Azospirillllm gen nov., and two species Azospirillum lipoferum comb, nov., and Azospirillllm brasilense sp., nov. Can. J. Microbiol. 24:967-980.

34. Uknes, S., Dincher, S., Friedrich, L., Negrotto, D., Williams, S., Thompsontaylor, H., Potter, S., Ward, E., and Ryals, J. 1993. Regulation of pathogenesis-related protein-1a gene-expression in tobacco. Plant Cell 5:159-169.

35. van Loon, L. C., Bakker, P. A. H. M., and Pieterse, C. M. J. 1998. Systemic resistance induced by rhizosphere bacteria. Annu. Rev. Phytopathol. 36:453-483.

36. van Peer, R., Niemann, G. J., and Schippers, B. 1991. Induced resistance and phytoalexin accumulation in biological control of Fusarium wilt of carnation by Pseudomonas sp. strain WCS417r. Phytopathology 91:728734.

37. van Wees, S. C. M., Luijendijk, M., Smoorenburg, I., van Loon, L. C., and Pieterse, C. M. J. 1999. Rhizobacteria-mediated induced systemic resistance (ISR) in Arabidopsis is not associated with a direct effect on expression of known defense-related genes but stimulates the expression of the jasmonate-inducible gene Atvsp upon challenge. Plant Mol. Biol. 41:537-549.

38. Wei, G., Kloepper, J. W., and Tuzun, S. 1991. Induction of systemic resistance of cucumber to Colletotrichum orbiculare by select strains of plant-growth promoting rhizobacteria. Phytopathology 81:1508-1512.

39. Whipps, J. M. 2001. Microbial interactions and biocontrol in the rhizosphere. J. Exp. Bot. 52:487-511.

40. Yamaguchi, T., Ito, Y., and Shibuya, N. 2000. Oligosaccharide elicitors and their receptors for plant defense responses. Trends Glycosci. Glyc. 12:113-120.

41. Zehnder, G. W., Murphy, J. F., Sikora, E. J., and Kloepper, J. W. 2001. Application to rhizobacteria for induced resistance. Eur. J. Plant Pathol. 107:39-50.

42. Zeidler, D., Zahringer, U., Gerber, I., Dubery, I., Hartung, T., Bors, W., Hutzler, P., and Durner, J. 2004. Innate immunity in Arabidopsis thaliana: Lipopolysaccharides activate nitric oxide synthase (NOS) and induce defense genes. Proc. Natl. Acad. Sci. USA 101:15811-15816. 